\title{
ARTIKKELIT
}

\section{ע Muistisairaiden ja puoliso-omaishoitajien kokemuksia tuen riittämättömyydestä}

\author{
Lina Van Aerschot ${ }^{1}$, Päivi Eskola ${ }^{2}$, Mari Aaltonen ${ }^{3}$ \\ ${ }^{1}$ Humanistis-ybteiskuntatieteellinen tiedekunta, Ikääntymisen ja \\ hoivan tutkimuksen huippuyksikkö, Jyväskylän yliopisto \\ ${ }^{2}$ Liikuntatieteellinen tiedekunta, Gerontologian tutkimuskeskus ja \\ Avoin yliopisto, Jyväskylän yliopisto \\ ${ }^{3} Y$ Yteiskuntatieteiden tiedekunta (terveystieteet) ja Gerontologian tutkimuskeskus, \\ Tampereen yliopisto
}

\begin{abstract}
Muistisairautta sairastavien ikääntyneiden kotona asuminen onnistuu usein omaishoitajien avulla, mutta tukea tarvitaan myös sosiaali- ja terveyspalveluista. Aina kaikki eivät kuitenkaan saa riittävää apua ja tukea. Niin muistisairautta sairastavat ihmiset kuin omaishoitajatkin voivat kärsiä avun riittämättömyydestä. Tässä artikkelissa tutkimme, millaista tukea muistisairaat ja heidän puolisonsa kaipaavat ja millaisia kokemuksia heillä on avun riittämättömyydestä. Tutkimuksemme mukaan muistisairautta sairastavien ikääntyneiden ja omaishoitajien kohtaama avun riittämättömyys liittyy sekä palvelujärjestelmään ja erilaisiin tukimuotoihin että henkisen tuen tarpeisiin. Muistisairautta sairastavat ja heidän omaishoitajansa eivät niinkään kohtaa tilanteita, joissa he eivät saisi lainkaan tarvitsemaansa apua, mutta saatu apu ei aina vastaa tarpeita tai se on liian vähäistä. Omaishoitajat myös paikkaavat palvelujärjestelmän puutteita ottamalla vastuun puolisonsa hoivasta tilanteissa, joissa julkiset palvelut ovat riittämättömiä tai niitä ei ole saatavilla. Kotona asumisen tueksi tarvittava apu on riittämätöntä useammin omaishoitajien kuin heidän muistisairautta sairastavien puolisoidensa kannalta. Usein tämä tarkoittaa sitä, että omaishoitajat kantavat vastuuta hoivasta oman jaksamisensa kustannuksella.
\end{abstract}

\section{Johdanto}

Suomessa ikääntyneet ihmiset asuvat mahdollisimman pitkään kotonaan, myös silloin, kun heillä on muistisairaus. Usein tämä on mahdollista läheisten tuella tai omaishoitajan huolenpidon ansiosta. Läheisiltään apua saavat muistisairautta sairastavat ihmiset käyttävät vähemmän ympärivuorokautisen hoidon ja sairaala- hoidon palveluja kuin ilman läheisten apua olevat muistisairaat (Heikkilä ym. 2020). Kotona asumiseen tarvitaan kuitenkin tukea myös julkisista tai yksityisistä palveluista, erityisesti kun kyseessä on pitkälle edennyt muistisairaus (Jensen \& Inker 2015). Sen lisäksi, että palvelut auttavat muistisairautta sairastavaa henkilöä, niiden tarkoituksena on tukea myös omaisen jaksamista (McCabe ym. 2018). 
Terveyden ja hyvinvoinnin laitoksen mukaan muistisairautta sairastavia henkilöitä arvioidaan olevan Suomessa noin 200000 ja määrä kasvaa vuosittain tuhansilla (THL 2019). Samalla muistisairautta sairastavien asiakkaiden lukumäärä ja osuus kaikista sosiaali- ja terveyspalvelujen asiakkaista kasvaa (THL 2017). Muistisairaudet ovat keskeisin syy toimintakyvyn heikkenemiseen, avun ja tuen tarpeeseen sekä ympärivuorokautisen hoivan tarpeeseen (Eloniemi-Sulkava ym. 2008; Finne-Soveri ym. 2015). Etenevä muistisairaus tarkoittaa neurologista oireyhtymää, joka vähitellen heikentää kognitiivisia kykyjä, opittuja taitoja ja fyysisiä suorituksia. Etenevä muistisairaus vaikeuttaa itsenäistä elämää, kun arjen toiminnoista, esimerkiksi kodin ulkopuolella liikkumisesta, syömisestä tai pukeutumisesta, tulee hankalaa. Sairauteen voi liittyä myös kielellisiä vaikeuksia ja levottomuutta sekä psyykkisiä ja käyttäytymiseen vaikuttavia muutoksia. (Viramo \& Sulkava 2015.) Muistisairautta sairastavan persoona saattaa muuttua, mikä vaikuttaa läheissuhteisiin (Pozzebon ym. 2016).

Muistisairauden aiheuttamat muutokset johtavat avun tarpeisiin ja voivat aiheuttaa läheisille kuormitusta ja stressiä. Muistisairasta läheistään hoitavat omaishoitajat kaipaavat arjen tueksi palveluja ja mahdollisuutta vapaapäiviin vuorohoidon tai sijaisjärjestelyjen avulla. Lisäksi omaishoitajat kaipaavat henkistä tukea, kuten vertaistukea, keskusteluapua ja neuvontaa (Shemeikka ym. 2017; Ringer ym. 2018). Tuen ja palvelujen pitää kuitenkin olla omiin tarpeisiin sopivia ja luotettavia, jotta omaishoitajat haluavat ja uskaltavat niitä käyttää (Mikkola 2009).

Niin perustuslain kuin vanhuspalvelulain ja sosiaalihuoltolain mukaan kotona asuvien muistisairautta sairastavien ja heidän perheidensä saatavilla tulisi olla heidän tarvitsemaansa tukea. Perusterveydenhuollon lääkäri, kotisairaanhoidon ja kotipalvelun työntekijät, muistikoordinaattorit ja perustason sosiaalialan ammattihenkilöt ovat kotona asuvan muistipotilaan ensisijainen ammatillinen tukiverkosto.
Erityisesti lääkärin ja muistihoitajan vastuulla on antaa potilaalle ja omaiselle heidän kaipaamaansa tukea, tietoa ja neuvontaa saatavilla olevista palveluista ja tukimuodoista. Kunnallisten palvelujen lisäksi muistisairauteen sairastuneille ja heidän läheisilleen ovat tärkeitä myös erilaiset yhdistysten ja kolmannen sektorin tarjoamat palvelut (Eloniemi-Sulkava ym. 2015). Tutkimusten perusteella kuitenkin tiedetään, että kaikki ikääntyneet ihmiset eivät saa tarvitsemaansa apua (Kröger ym. 2018). Avun riittämättömyys on Suomessa yleisempää muistisairautta sairastavilla kuin muilla iäkkäillä, vaikka he saisivat apua ja hoivaa sekä omaisilta että palveluista (Aaltonen \& Van Aerschot 2021).

Tässä tutkimuksessa tarkastelemme muistisairautta sairastavan henkilön ja häntä hoitavan puolison kuvauksia tilanteista ja hoivan osa-alueista, joissa he kokevat avun riittämättömyyttä tai kaipaisivat lisää apua.

\section{Omaishoito Suomessa}

Omaisten ja läheisten tarjoama apu on Suomessa yleistä.Yli 70-vuotiaiden kotona asuvien suomalaisten on todettu saavan enemmän apua omaisiltaan kuin palveluista. Eniten apua antavat puolisot, lapset sekä lasten puolisot. (Blomgren ym. 2006; Van Aerschot 2014.) Omaistaan hoitava läheinen voi kuulua virallisen omaishoitosopimuksen piiriin. Tällöin kunnan ja omaishoitajan välillä tehdään sopimus vajaatoimintakykyisen, sairaan tai vammaisen henkilön hoidosta ja huolenpidosta kotona. Sopimuksessa määritellään omaishoitajan tuki eli sovitaan hoidettavan tarvitsemista palveluista, omaishoitajan hoitopalkkiosta, vapaista ja omaishoitajan hoitotehtävää tukevista palveluista (Laki omaishoidon tuesta, 2.12.2005/ 937). Lisäksi omaishoitoa voidaan tukea esimerkiksi kotihoidon palveluilla, päiväkeskustoiminnalla tai vaikkapa järjestöjen vertaistuki- tai virkistystoiminnalla.

Omaishoitajien liiton (2020) mukaan omaishoitaja on henkilö, joka "pitää huolta perheen- 
jäsenestään tai muusta läheisestään, joka sairaudesta, vammaisuudesta tai muusta erityisestä hoivan tarpeesta johtuen ei selviydy arjestaan omatoimisesti”. Omaishoitajaliiton määritelmän mukaisesti Suomessa on noin 350000 läheisestään huolehtivaa omaishoitajaa (Sosiaalija terveysministeriö 2014), mutta heistä vain 47500 on virallisen sopimuksen tehneitä omaishoitajia (THL 2020). Niillä omaishoitajilla, jotka hoitavat läheistään ilman virallista omaishoitosopimusta, ei ole oikeutta sopimuksen mukanaan tuomaan tukeen tai palveluihin, kuten omaishoitajalle suunnattuun valmennukseen ja koulutukseen, tai kuukausittaisiin vapaapäiviin (Kuntaliitto 2020).

Huonokuntoiset ja paljon apua tarvitsevat ihmiset saavat usein apua sekä palveluista että läheisiltään. Läheisiltä saadun avun määrän on todettu olevan suurempi kuin palveluista saadun avun määrä (Finne-Soveri ym. 2014). Puolisolta saatu apu ylitti virallisen avun jopa kymmenkertaisesti, kun sitä mitattiin avun antamiseen käytettyinä tunteina viikon aikana. Kaikkein huonokuntoisimpien avun tarvitsijoiden puolisot huolehtivat kumppanistaan jopa yli 70 tuntia viikossa. (Finne-Soveri ym. 2014.) Pelkästään niiden omaishoitajien, jotka tekivät sitovaa omaishoitoa ilman korvausta, arvioitiin vuonna 2013 tuottavan 338 miljoonan euron vuosittaiset säästöt (Kehusmaa ym. 2013). On arvioitu, että ilman omaisten hoivan ja hoidon panosta ikääntyneiden hoidon menot olisivat Suomessa kaikkiaan jopa 2,8 miljardia euroa suuremmat (Kehusmaa 2014). Omaishoidossa ja sen tukemisessa on siis kyse suurista yhteiskunnallisista ja taloudellisista ratkaisuista.

Hoivatilanteet kodeissa voivat olla kuormittavia niin apua tarvitseville ikääntyneille kuin heitä hoitaville omaisille. Muistisairaan läheisillä on tutkimuksissa todettu riski kokea stressiä ja masennusta (Ringer ym. 2018). Omaishoitajan kuormitusta vähentävät tekijät pienentävät hoidettavan riskiä joutua laitoshoitoon. Tärkein kuormitusta helpottava tekijä on riittävien tukipalvelujen saaminen. (Jarrot ym. 2005; Mossello ym. 2008.) Aikaisemman tutkimuk- sen mukaan muistisairautta sairastavaa läheistään hoitavat omaiset kaipaavat tuekseen erityisesti tietoa muistisairaudesta ja sen etenemisestä, neuvoja ja ohjeita muistisairaan kanssa toimimiseen sekä tietoa saatavilla olevista palveluista (Chester ym. 2018; Ringer ym. 2018). Omaistaan hoitavilla on tarvetta myös henkiselle tuelle ja vertaistuelle, joka auttaisi suhtautumaan muistisairauden aiheuttamiin persoonallisuuden ja käyttäytymisen muutoksiin (McCabe ym. 2016; Tatangelo ym. 2018). Omaishoitajan ja hoidettavan suhde muuttuu väistämättä, ja siihen sopeutuminen voi olla todella vaativaa (Feast 2016).

Lyhytaikaishoito, joka mahdollistaa omaishoitajan vapaapäivät, on tutkimuksissa todettu yhdeksi tärkeimmistä keinoista tukea omaishoitajien jaksamista. Lisäksi se mahdollistaa sosiaalisten suhteiden ylläpitämisen ja omasta terveydestä huolehtimisen (Stoltz ym. 2004; Salin \& Åsted-Kurki 2007; Luchetti ym. 2009). Omaishoitajien on kuitenkin todettu olevan halukkaita käyttämään lyhytaikaishoitoa vain silloin, kun omaishoitoa saava henkilö on siihen suostuvainen eikä hoitopaikkaan meneminen vaikuta häneen ei-toivotusti (van Exel ym. 2006; Phillipson ym. 2013).

\section{Avun riittämättömyys ja muistisairaus}

Avun riittämättömyyttä on tutkittu jo pitkään gerontologisessa tutkimuksessa käyttäen käsitettä unmet needs. Sillä tarkoitetaan tilannetta, jossa ihmisellä on heikentyneestä toimintakyvystä johtuvia avuntarpeita, mutta apua ei ole saatavilla tai se ei ole riittävää (esim. Lima \& Allen 2001; Vlachantoni 2019). Alun perin Bernard Isaacs ja Yvonne Neville (1976) määrittelivät avun riittämättömyyden tilanteeksi, jossa ikääntynyt ei saa perustarpeidensa täyttämiseen tarpeeksi apua ja/tai avun antaminen aiheuttaa lähiomaisille kohtuutonta kuormitusta. Avun riittämättömyyden voikin ajatella kohdistuvan yhtä hyvin läheisestään huolehtiviin omaisiin kuin apua tarvitsevaan ihmiseen 
itseensä. Voidaan ajatella, että avun riittämättömyyden seuraukset siirtyvät omaisille, kun he kantavat hoivavastuun eivätkä saa siihen riittävää tukea.

Britanniassa julkaistun haastatteluaineistoon perustuvan tutkimusraportin (Blake ym. 2017) mukaan avun riittämättömyys ei nykyään juurikaan liity perustarpeisiin, kuten ravitsemukseen tai turvallisuuteen, vaan se koskee tarpeita, jotka jäävät helpommin huomaamatta. Avun riittämättömyys aiheuttaa usein yksinäisyyttä ja sosiaalista eristyneisyyttä, sitä ettei pääse ulos kodistaan eikä pysty osallistumaan toimintaan kodin ulkopuolella. Muistisairautta sairastavilla ihmisillä riittämätön avunsaanti on yleistä (Black ym. 2013; Kerpershoek ym. 2018) ja yleisempää kuin muilla apua tarvitsevilla (Zhou ym. 2018, Aaltonen \& Van Aerschot 2021).

Kun ihmisellä on paljon avun ja hoivan tarpeita, avun riittämättömyyden riski kasvaa. Etenevää muistisairautta sairastavilla on usein suuri määrä erilaisia avun ja hoivan tarpeita. Alzheimerin taudissa lähimuisti ja uuden oppiminen vaikeutuvat. Kielellisiä vaikeuksia ja puheen ymmärtämisen ongelmia ilmaantuu sairauden edetessä, ja ihmisten tai esineiden tunnistaminen ja ympäristössä liikkuminen vaikeutuvat. Lisäksi organisointikyky, toiminnan suunnittelu ja aloitekyky heikkenevät. (Juva 2018.) Frontotemporaaliseen eli otsalohkodementiaan ei liity niinkään muistiongelmia vaan persoonan ja käyttäytymisen muutoksia, psyykkisiä oireita ja puheongelmia (Remes ym. 2018). Vaskulaarinen dementia aiheuttaa toiminnanohjauksen heikentymistä sekä neurologisia oireita, kuten kävelyn ja puheentuoton ongelmia, enemmän kuin muistihäiriöitä. Oireet voivat vaihdella paljon, koska eri aivoverenkiertohäiriöiden aiheuttamat puutosalueet voivat olla erikokoisia ja sijaita missä tahansa aivojen osassa (Atula 2019). Sekamuotoisessa dementiassa esiintyy useamman kuin yhden sairaustyypin oireita. Muistisairauden tyyppi ja sairauden yksilöllinen eteneminen siis määrittävät sitä, millaisia oireita ja millaisia avuntarpeita ihmisellä on.

\section{Aineisto}

Aineistomme sisältää 19 temaattista, puolistrukturoitua teemahaastattelua, jotka on kerätty vuosina 2018-2019. Haastatteluihin osallistui 34 henkilöä, jotka olivat puolisoaan hoitavia omaishoitajia (19) ja heidän diagnosoitua muistisairautta sairastavia puolisoitaan (15). Haastateltavista muistisairaista yhdeksän oli miehiä ja kuusi naisia; omaisista kuusi oli miehiä ja 13 naisia. Muistisairauteen sairastuneet olivat 65-88-vuotiaita, ja heidän keski-ikänsä oli 76 vuotta. Puoliso-omaishoitajat olivat 6287-vuotiaita, ja heidän keski-ikänsä oli 75 vuotta.

Osallistujat tavoitettiin Muisti- ja Omaishoitajaliittojen jäsenyhdistysten kautta. Tutkijat ottivat yhteyttä jäsenyhdistyksiin ja kertoivat hankkeesta. Tämän jälkeen tutkijat kävivät kertomassa tutkimushankkeesta omaishoitajille ja heidän puolisoilleen kahden jäsenyhdistyksen tilaisuudessa. Osa haastateltavista ilmoittautui halukkaaksi tutkimukseen tuossa tilaisuudessa ja osa otti yhteyttä haastattelijaan myöhemmin puhelimitse.

Tavoitteena oli, että haastattelussa olisivat molemmat osapuolet, sekä omaishoitaja että muistisairautta sairastava itse, jolloin kummankin näkemykset tulisivat esiin ja puoliso pystyisi tukemaan sairastunutta haastattelun aikana. Haastateltavat saivat itse valita, miten haastattelut järjestettiin. Kolme pariskuntaa halusi antaa haastattelut erikseen, ja viisi omaishoitajaa halusi osallistua haastatteluun yksin, koska he arvioivat, että puoliso oli liian huonokuntoinen osallistumaan. Muut osallistuivat haastatteluihin yhdessä. Suurin osa, 28 henkilöä, halusi tehdä haastattelun omassa kodissaan. Muut haastattelut tehtiin muistiyhdistysten tiloissa.

Sairastuneista puolisoista 13 henkilöä sairasti Alzheimerin tautia, kahdella oli diagnosoitu otsalohkodementia, kahdella vaskulaarinen dementia ja kahdella sekamuotoinen dementia. Luvuissa ovat mukana niidenkin henkilöiden diagnoosit, jotka eivät itse pystyneet osallistumaan haastatteluun ja haastateltavana oli vain omaishoitajana toimiva puoliso. 
Muistisairautta sairastavien haastateltavien tai heidän omaistensa arvio sairauden asteesta vaihteli lievästä vaikeaan. Pitkälle edenneessä muistisairaudessa sairastuneen henkilön voi olla vaikea ymmärtää omien päätöstensä merkityksiä ja seurauksia tai esimerkiksi tutkimushaastattelun tarkoitusta. Varmistaaksemme, että haastatteluihin osallistuvat muistisairautta sairastavat henkilöt olivat tietoisia, mistä haastatteluissa on kyse, ja että he olivat kykeneviä osallistumaan haastatteluihin, aineistonkeruu toteutettiin tiiviissä yhteistyössä puolisoomaishoitajien kanssa. Muistisairauden etenemisen asteesta kysyttiin haastattelutilanteessa haastateltavilta, joilla on ajantasaisin tieto ja kokemus muistisairautta sairastavan henkilön tilanteesta.

Muistisairautta sairastavien ihmisten osallistaminen tutkimushaastatteluun vaatii haastattelijalta keskustelutilanteessa herkkyyttä haastateltavan reaktioille ja viesteille, tilanteeseen sitoutumista ja toisen ihmisen tunnustamista ja kunnioitusta (Digby ym. 2016). Lisäksi haastattelutilanteeseen kannattaa varata aikaa sekä joustavuutta (Hubbard ym. 2003). Tässä tutkimuksessa aineistona olevat haastattelut keräsi kaksi tutkijaa. He ovat molemmat työskennelleet muistisairautta sairastavien parissa ja olivat siten tietoisia haasteista, joita muistisairaus voi tuoda keskustelutilanteeseen.

Taulukko 1. Haastatteluihin osallistuneet omaishoitajat ja muistisairautta sairastavat henkilöt (nimet muutettu).

\begin{tabular}{|c|c|c|c|c|}
\hline $\begin{array}{l}\text { Puoliso- } \\
\text { omaishoitaja }\end{array}$ & $\begin{array}{l}\text { Haastatteluun } \\
\text { osallistunut } \\
\text { muistisairas } \\
\text { henkilö } \\
\end{array}$ & $\begin{array}{l}\text { Muistisairas henkilö, } \\
\text { joka ei osallistunut } \\
\text { haastatteluun }\end{array}$ & $\begin{array}{l}\text { Omaishoito- } \\
\text { sopimus }\end{array}$ & Muuta \\
\hline Aila & & Olli & Kyllä & \\
\hline Aulis & Anja & & $\mathrm{Ei}$ & \\
\hline Elina & Erkki & & $\mathrm{Ei}$ & \\
\hline Helena & & Heikki & Kyllä & \\
\hline Irma & & Aarne & Kyllä & \\
\hline Kaisa & & Kauko & Oli & $\begin{array}{l}\text { Puoliso saanut hiljattain } \\
\text { paikan hoitokodissa }\end{array}$ \\
\hline Lasse & Leena & & Kyllä & \\
\hline Maire & & Markku & $\mathrm{Ei}$ & $\begin{array}{l}\text { Mairella olemassa myös } \\
\text { oma koti }\end{array}$ \\
\hline Marianne & Martti & & $\mathrm{Ei}$ & \\
\hline Mikko & Mari & & Kyllä & \\
\hline Olavi & Orvokki & & $\mathrm{Ei}$ & \\
\hline Pirkko & Pekka & & $\mathrm{Ei}$ & $\begin{array}{l}\text { Ei riittämättömän avun } \\
\text { kuvausta }\end{array}$ \\
\hline Rauha & Risto & & Kyllä & $\begin{array}{l}\text { Ei riittämättömän avun } \\
\text { kuvausta }\end{array}$ \\
\hline Riitta & Reijo & & $\mathrm{Ei}$ & \\
\hline Sauli & Sirpa & & $\mathrm{Ei}$ & $\begin{array}{l}\text { Ei riittämättömän avun } \\
\text { kuvausta }\end{array}$ \\
\hline Taina & Tarmo & & Kyllä & \\
\hline Tyyne & Toivo & & $\mathrm{Ei}$ & \\
\hline Tuomas & Tiina & & Kyllä & \\
\hline Valma & Ville & & Kyllä & \\
\hline
\end{tabular}


Teemahaastattelurungossa oli kuusi laajempaa teemaa: 1) muistisairauden ilmeneminen, 2) avun ja tuen tarve sekä läheisapu ja palvelut, 3) sosiaaliset suhteet / ihmissuhteet, 4) asunto ja elinympäristö, 5) teknologian käyttö arjessa sekä 6) omaishoitajan jaksaminen. Palvelutarpeista kysyttiin esimerkiksi:"Millaista apua saatte sosiaali- ja terveyspalveluista?" "Saatteko riittävästi apua kotiin?" "Onko jotain sellaista apua tai hoitoa, mitä koette tarvitsevanne, mutta ette ole saaneet?" Haastateltavat saivat vapaasti ohjata keskustelua ja ottaa esille tärkeiksi kokemansa asiat, vaikka ne eivät olisi liittyneet suoraan haastattelun teemoihin.

Aineistoa kerättiin eri puolilta Suomea.Tampereen alueen ihmistieteiden eettinen toimikunta antoi tutkimuksen toteuttamiselle puoltavan päätöksen (Päätös 37/2018). Jokainen osallistuja antoi henkilökohtaisen tietoon perustuvan kirjallisen suostumuksensa haastatteluun osallistumiseen ja haastattelun nauhoittamiseen. Haastateltaville kerrottiin tarkoin, että osallistuminen on vapaaehtoista ja sen voi peruuttaa missä vaiheessa tahansa. Myös jälkeenpäin on mahdollista kieltää haastattelun käyttö tutkimusaineistona. Tutkimuksen tarkoitus sekä aineiston käsittelyyn ja tallentamiseen liittyvät tiedot kerrottiin osallistujille sekä suullisesti että erillisellä tiedotteella, jossa oli myös tutkimuksesta vastaavan tutkijan yhteystiedot lisätietojen ja tarkennusten kysymistä varten. Aineisto kerättiin Euroopan unionin yleisen tietosuoja-asetuksen 2016/679 mukaisesti. Litteroiduista haastatteluista poistettiin nimi, asuinpaikka ja ammattitiedot anonymiteetin turvaamiseksi, ja nimet korvattiin pseudonyymeilla. Haastattelut kestivät tunnista kahteen tuntiin. Litteroitua haastattelutekstiä oli yhteensä 811 sivua; kirjasintyyppinä oli Verdana, fonttikoko 8 ja riviväli 1 .

Haastatteluista kolme ei sisältänyt riittämättömän avun kuvauksia. Näistä osa kuvasi avuntarpeiden olevan vähäisiä lievän muistisairauden vuoksi ja osa kertoi saavansa apua ja tukipalveluja riittävästi. Nämä haastattelut oli- vat kuitenkin osa aineistoa, sillä nekin luettiin analyysiä varten.

Omaishoitajalla tarkoitamme Omaishoitajaliiton määritelmän mukaisesti toimintakyvyn alentumisen vuoksi apua tarvitsevaa läheistään hoitavaa ihmistä, olipa tällä virallista omaishoitosopimusta tai ei.

\section{Menetelmät}

Avun riittämättömyydestä Suomessa tehty tutkimus on aiemmin perustunut määrälliseen aineistoon (esim. Kröger ym. 2019; Aaltonen \& Van Aerschot 2021). Tämä tutkimus perustuu laadulliseen aineistoon, jonka avulla on mahdollista kuvata tarkemmin, millaisiin asioihin ja tilanteisiin avun riittämättömyys liittyy, miten se ilmenee ja millaista tukea omaishoitajat ja muistisairaat haluaisivat ja tarvitsisivat.

Analyysimme lähtökohtana ovat tutkimuskirjallisuudessa esitetyt riittämättömän avun määritelmät (Isaacs \& Neville 1976; Blake ym. 2017; Kröger ym. 2019; Vlachantoni 2019). Aineiston analyysissa haluttiin kuitenkin antaa tilaa myös sille, miten haastateltavat itse kuvasivat elämäntilannettaan, ja niitä asioita, joissa he tarvitsevat enemmän apua ja tukea kuin mitä he saavat, tai miten he kuvasivat kohtaamiaan haasteita. Analyysimenetelmäämme voi nimittää teoriaohjaavaksi sisällönanalyysiksi, jossa yhdistellään aikaisemmasta tutkimuskirjallisuudesta ja teoriasta johdettuja sekä aineistolähtöisiä luokitteluja (Silvasti 2014, 43-44). Teoriaohjaavalle analyysille ovat ominaisia teoreettiset kytkennät, mutta ei suora teoriaan pohjautuminen. Analyysiyksiköt nostetaan aineistosta, mutta aikaisemman tiedon ja tutkimuksen vaikutus on tunnistettavissa. Analyysin teossa vaihtelevat aineistolähtöisyys ja valmiit mallit (Tuomi \& Sarajärvi 2009, 97).

Kun haastatteluissa kysyttiin suoraan, saavatko omaishoitajat ja muistisairaat tarpeeksi apua ja tukea, he useimmiten vastasivat, että pärjäävät ihan hyvin eikä avun riittämättömyys 
ole ongelma. Haastateltavat kuvasivat kuitenkin monenlaisia tilanteita,joissa omaishoitajan vastuu on kohtuuttoman suuri tai joissa hän hoitaa toistuvasti tehtäviä, joiden takia hänen oma hyvinvointinsa kärsii. Määrittelimme omaishoitajien kuvaamat raskaat ja vaikeat tilanteet kuvauksiksi avun riittämättömyydestä perustuen Isaacsin ja Nevillen (1976) määritelmään, jonka mukaan avun riittämättömyyttä on myös se, että avun antaminen aiheuttaa lähiomaisille kohtuutonta kuormitusta. Haastateltavat kuvasivat myös avun riittämättömyyttä, joka liittyi siihen, etteivät saatavilla olevat palvelut olleet tarpeenmukaisia, oikea-aikaisia tai riittävän laadukkaita. Siten tulkitsemme aineistosta avun riittämättömyyden kuvauksia haastateltavien kerronnasta myös sellaisissa kohdissa, joissa he eivät suoraan sano, että apu on riittämätöntä.

Analyysimme eteni siten, että luimme haastattelut huolellisesti ja keskustelimme yhdessä riittämättömän avun kuvauksista. Haimme keskusteluissa yhteistä käsitystä siitä, mitä asioita määrittelemme riittämättömäksi avuksi aikaisemman tutkimuksen ja oman käsityksemme perusteella. Keskustelujen jälkeen koodasimme tekstiä etsimällä haastatteluista riittämätöntä apua ja tuen tarpeita koskevat aineistokatkelmat. Tämän jälkeen muodostimme haastatteluissa esiin tulleista avun riittämättömyyttä kuvaavista aineistokatkelmista neljä pääteemaa: 1) vuorohoito, 2) kotihoidon palvelut ja muut kotona asumisen tukipalvelut, 3) pääsy lääkäriin ja luotettava hoitosuhde sekä 4) henkinen tuki.

\section{Tulokset}

\section{Vuorohoito}

Mahdollisuus vapaapäiviin, lepoon ja omaan aikaan on omaishoitajien jaksamisen kannalta tärkeää. Vuorohoidon on tarkoitus mahdollistaa omaishoitajan vapaapäivät ja irrottautuminen hoivavastuista. Omaishoitajasopimuksen tehneet hoitajat ovat oikeutettuja vapaapäiviin, ja kunnan on tarjottava hoidettavalle hoitopaikka tai omaishoitajan sijainen tälle ajalle (Laki omaishoidon tuesta 2.12.2005/937). Viisi haastatelluista omaishoitajista kertoi, ettei halua tai pysty käyttämään vuorohoidon palvelua. Sekä omaishoitajat että muistisairaat itse olivat kokeneet olosuhteet vuorohoitopaikoissa sellaisiksi, että niihin ei haluta enää mennä. Usein ongelmat liittyivät siihen, että vuorohoidossa ei saatukaan sitä hoitoa ja tukea, jota oli luvattu hoitojaksoa suunniteltaessa, tai hoitopaikassa saatu hoiva ja huolenpito koettiin liian heikoksi tai jopa olemattomaksi. Joskus omaishoitaja oli sitä mieltä, että oma puoliso tuli vuorohoitojaksolta takaisin kotiin heikommassa kunnossa kuin oli lähtiessä tai että vuorohoito oli ylipäätään omalle puolisolle väärä paikka.

Taina, omaishoitaja: Mä vein bänet sitte 'Koivulaan', ku minusta tuntu et mä en pärjää, ku bälle piti pistääki niitä piikkejä [...] mutta sekin oli vähän semmonen [...] siel on näitä kissoja, niin ne juoksi siel hänenkin makuuhuoneessaan, jossa se oli sitten pöydällä se CPAP-laite [...] et se pitää pestä joka päivä ja olla bygieeninen sen kans, ni musta se ei ollu ihan hyvä paikka. Sit siel oli muutenkin semmosta niin paljo buonokuntosta, ni mä aattelin, että heidän joukkoonsa laittaa, niin ei tunnu hyvältä, varmaan hirveen masentavaa. [...] niin nyt sitte kesäkuussa, ni mä aattelin, että mäki kokeilen, ku mä en ollu koko alkuvuonna pitäny siis ybtään päivää [vapaata]. Täähän vaikutti hyvältä paikalta tää 'Minttu', sielläbän sairaanhoitaja keskusteli mun kans ennakkoon 40 minuuttia. [...] Mut kyl se nyt jälkeenpäin sitten osotti, että ei siellä ainakaan hän parempaan kuntoon tuu. Että huonompaan menee.

Aila, omaishoitaja: 'Syysleimu' on tämä intervalli-ja kuntoutushoito-osasto. Ja se [puoliso Olli] oli siellä yhen viikon, kun mä olin tosi poikki, [...] ja se oli ihan väärä paikka sille. 
Haastattelija: Minkä takia se oli väärä?

Aila: No ensiksi ku Olli ei oo ihan vielä töotissä, että sitä markkinoitiin Ollille, että se on kuntoutuspaikka, jossa kuntoutetaan, ja puhuttiin, että ku sil on jalat huonot, että siel on kuntoutusohjaaja, joka kuntouttaa sen jalkoja. Sitte ku sil oli menny justiin sillon ajokortti, ni ne lupas, että yrittää psykiatrian sairaanhoitajat pubua tästä asiasta sille ja sitte siellä luvattiin kaikkea muutaki. Ja ku me mentiin sinne sillon ybtenä sunnuntaina sinne, ni se oli... Ne ol siis lukkojen takana, että siel ei pääse piballe ollenkaa, ku siel on niin paljon buonojaki... Mentiin, ni se jäi sinne ja kaikki oli niin buonoja, että ne ei ollu ollenkaan tuon kuntosia ku Olli. Ja yhen kerran kävi kuntohoitaja kabtomassa sen jalkoja, eikä ybtään kertaa käyny kukaan sairaanhoitajakaan puhumassa sille mistään näistä asioista mitä se ois halunnu pubua, se oli täysin siellä yksin niitten ibmisten kans, et ei ollu minkäänlaista juttuseuraa, ei mitää. Ja kaikki luvattiin ja mitään ei toteutettu. Ni se kuntoutusosasto on meillä pois laskuista, se ei suostu sinne läbtemään, enkä mä suostu sitä sinne viemään. [...] Että pitäs olla joku muu paikka. [...] Ja tää on nyt justii joka kannattaa ottaa tosissaan tämä asia [vuorohoidon mahdollistaminen], että tää on niinku ihan elintärkee.

Haastateltavat olivat pettyneitä vuorohoidon laatuun ja siihen, että perusasioista, kuten wc:hen auttamisesta ja lääkintälaitteiden hygieniasta, ei huolehdittu kunnolla. Omaishoitajia myös suretti, jos oma puoliso joutui osastolle, jossa muut olivat huomattavasti huonokuntoisempia. Kun vuorohoito-osastolla tarjottu hoito oli yksinkertaisesti liian heikkolaatuista, omaishoitajat eivät käyttäneet sitä. He jättivät mieluummin oman, usein ainoan, mahdollisuutensa vapaa-aikaan käyttämättä, jos vuorohoito tarjosi riittämätöntä apua.

Tuomaksen puolison Tiinan muistisairaus oli jo sellaisessa vaiheessa, ettei häntä voinut "silmistänsä jättää". Vuorohoitopaikasta oli ollut huonoja kokemuksia jo vuotta aiemmin, eikä
Tuomas kokenut, että se oli hänelle mitään lomaa,"kun joka ilta soitti ja kävi siellä ja jännitti, mitä siellä tapahtuu".

Tuomas, omaishoitaja: Mutta tuota, 'Maijala' oli sellanen paikka et sielä lääkittiin, niin pitkälle, että siellä ei pysty häiriköimään. Ja siellä pannaan vaippa housuun. Ei siellä kukaan ei tule neuvomaan missä vessa on. [...] Haastattelija: Niin justiin. Mut sen jälkeen ei oo ollu enää mitään tämmösiä hoitojaksoja? Tuomas: Ei ole ollu enkä mä vie. Se oli vabinko. [....] minä oon katunu. [....] Mutta se oli byvä. Minä pääsin näkemään mitä se on. Eihän siellä, potilaat istu ja tuijotti televisiota. Ne ei virkkanu mittään.

Tuomaksen mukaan vuorohoitopaikassa hoidon laatu on niin huonoa ja potilaiden olo ankeaa, ettei hän puolisoaan enää toiste sinne vie. Kuitenkin Tuomas puhuu toisessa kohdassa haastattelua siitä, että kaikki ovat huolissaan hänen jaksamisestaan ja huokaa, että "ku annettas niitä vapaapäiviä”.

Irman mies oli ollut viimeksi vuosi sitten vuorohoitojaksolla. Irma kertoi, että hän selviää kyllä päivärutiineista mutta on kroonisesti väsynyt, koska yöt ovat rankkoja. Hänelle on kertynyt univajetta jo pitkältä ajalta, sillä puoliso käy wc:ssä monta kertaa yössä ja Irman täytyy olla varmistamassa, ettei tämä kaadu. Puolisolle olisi tarjolla vuorohoitopaikka, mutta Irma kokee, ettei se ole tarpeeksi turvallinen, sillä varsinaista yövalvontaa ei ole, vaan hoitaja pitää kutsua paikalle soittamalla hälytyskelloa, mitä mies ei pysty enää tekemään. Puoliso ei myöskään halua mennä vuorohoitoon, joten Irman mahdollisuus lepoon ei toteudu.

Irma, omaishoitaja: Mie nukun hyvin tuonne aamuyöbön asti, mutta kun sitä pissaamista saattaa olla viis kuus kertaa yössä ja sitten mie en siinä välillä nuku ollenkaan. Mie vaan odotan sitä seuraavaa nousemista. [...] Nyt sitten tämä [lääkäri] sano, että pitäs harkita sitä [vuorohoitoa], kun meilläbän on se 
muistisairaiden tämmönen uus yksikkö siellä [...] Kun siellä on niinku se yöhoito. Mut ei siellä yöllä kukaan tule, muuta kun jos soittaa. Ja ei hän osaa soittaa. Ei ymmärrä sitä, vaikka hänelle sanois, että paina tuosta.

Valmalla on myös ollut kokemuksia siitä, että puolisolle ei tahdo löytyä hoitopaikkaa tai kotiin hoitajaa. Valman puoliso Ville tarvitsee katetrointia kahdesti päivässä, ja Valma hoitaa asian kotona. Kotiin on kuitenkin ollut vaikea saada hoitajaa, joka hoitaisi katetroinnin, eikä Villeä ole otettu kaikkiin hoitokoteihinkaan. Haastattelun ajankohtana Valmalla on jo omaishoitosopimus, ja nyt viralliset vapaajaksot on saatu järjestymään. Haastattelussa Valma kuvaa aikaa ennen virallisen omaishoitosopimuksen saamista:

Valma, omaishoitaja: [puoliso Villellä] on tuota katetrointi kaks kertaa päivässä, kun rakko ei tybjene. [...]

Haastattelija: Tota kuka sua opetti muuten siiben katetrointiin?

Valma: Tuolla terveyskeskuksessa ne sano, että "kyllä sinä siihen opit" ja ybtenä päivänä kävin, et näyttivät miten se tehään.

Haastattelija: Niin just, joo. Mut se on myöskin sitovaa.

Valma: On. Siis kun tuolla äsken kysyttiin rouvalta, että onko [mahdollista ottaa Ville hoidettavaksi] niin sano, että ei ole, heillä ei ole mahollisuutta, että he ottaa semmosta potilasta, jotka katetroijaan. Et niitä ei, ne on ihan sairaanhoitajat, tai sitten niinku, se vastuu on siirretty sairaanhoitajalta minulle, että ku siinä on ne omat riskinsä siinäkin hommassa. Villelläkkään ne hoitopaikat on vähiharvassa sitten, jossa se katetrointi pystytään tekemään.

Kaisan mies Kauko on siirtynyt juuri ennen haastattelun ajankohtaa ympärivuorokautiseen hoitoon. Tämä tapahtui niin, että Kauko joutui sairaalaan ja siellä huomattiin, ettei hän enää voi asua kotona. Kaisa kertoo haastattelussa hoitokotiin siirtymistä edeltävästä ajasta ja siitä, miten raskaaksi arki kävi ilman tarpeenmukaisia ja riittäviä palveluja ja tukea. Kaisa oli miehensä omaishoitaja pitkään ja haki intervallijaksopaikkaa vasta sitten, kun alkoi itse olla jo todella väsynyt. Kaukon saaminen hoitojaksolle oli kuitenkin hankalaa, ja lopulta intervallijaksotkaan eivät riittäneet tukemaan kotona-asumista.

Kaisa, omaishoitaja: Se oli niin kova taistelu, että lapsetki aina sanoo, että mä alan olla jo hermostunu kun se lähesty, että tuota pitäs saaba isäntä intervalliin.

Haastattelija: Millon se intervallihoito muute alko, et siinä ihan alkuvaiheessa ei varmaan ollu intervallia?

Kaisa: Ei, sitä ei ollu... Oiskohan se ollu nyt sitten, 2017, että ensin oli sillai, että bän oli kolme päivää. No siitä ei ollu mitään apua. [...] yks päivä oli siinä hengäbystä ja sitte [...] niin pantiin viikko siellä. Että viikkoki oli ja sitte pidennettiin vielä, että no kaks viikkoo oli siellä... Kumminki sitte, koska se, tuota alko käyä niinku [raskaaksi]... Ja monet aina sanoo, että pitää ajatella omaa terveyttä, mutta sitä ei niin helposti kyllä pysty ajattelemaan, että tuota, kun ei taho saaha sitä sinne intervalliin.

No sit meillä oli vielä tässä nyt viime kesänä se alko, hubtikuussa, niin Kauko ei saanu nukuttua. Ei millään. Sillä oli sydämen vajaatoiminta niin voi-, tuota että se jatkuvasti nousi pystyyn ja, ja tuota käveli yöllä ja niin siitä sitten tuonne kesäkuubun niin se oli kyllä ihan birvee aika, että ei nukkunu. Mää välillä aina jo ambulanssinkin tilasin, että tulkaa nyt, että mä en jaksa enää.

Kaisa kertoo, että intervallijaksot olivat aluksi riittämättömiä, mutta jaksoja pidennettiin kyllä hänen pyynnöstään. Hän kuitenkin väsyi täysin, kun tuli ajanjakso, jolloin puoliso ei juurikaan nukkunut. Kun Kaisa ei tiennyt, mitä tehdä pitkin yötä rauhattomana kulkevalle puolisolle, hän soitti ambulanssin. Hätäkeskuksen 
ei kuitenkaan kuuluisi olla se paikka, mistä omaishoitaja hakee apua muistisairaan puolisonsa öiseen levottomuuteen ja omaan uupumiseensa.

Kotihoidon palvelut ja muut kotona asumisen tukipalvelut

Vuorohoidon lisäksi omaishoitajat kertoivat tilanteista, joissa vastuu muistisairaan hoivasta kotona jäi heille, vaikka se tuntui oikeastaan liian vaativalta tai asetti omaishoitajan alttiiksi jopa väkivallalle. Haastateltavat eivät itse välttämättä erityisesti maininneet, että he tarvitsisivat apua kolmannelta taholta, kuten esimerkiksi kotihoidosta. Tilanteet saattoivat kuitenkin olla vaikeita, kuten Tyynellä, joka kertoi muistisairaan miehensä Toivon käyttäytyvän aggressiivisesti, kun hänen pitäisi peseytyä ja vaihtaa vaipat. Huono hygienia on jo aiheuttanut urologisia ongelmia, joiden takia on tarvittu lääkäriä.

Tyyne, omaishoitaja: Et tota, että just ollaan oltu urologin vastaanotolla [lääkäriaseman nimi] ja siellä sairaalassa tehtiin kaikki kokeet ja mäkin aattelin, että varmaan on jotain vakavaa ja hänkin [puoliso Toivo] itse väbän aatteli sitä, mutta ei oo mitään vakavaa, että ongelmia kyllä sen kanssa, bänen mielestään on. Mun mielestäni ei oo mitään ongelmia kunhan vaan bän sitten suostuu siihen, että vaibdetaan niitä vaippoja sillon kun tarvii. [...] Mut se on se ongelma meillä myöskin tää pubtaus... että se on se josta meillä ne nyrkit helposti heiluu... että ei, se pesulle meno on iban kaubeeta.

Toivo, muistisairautta sairastava puoliso: $\mathrm{Se}$ on ihan älytöntä.

Tyyne: [nauraa] Ei se oo älytöntä, se on kaks kertaa viikossa niin ei se oo paljon.

Myös Maire kertoo muistisairautta sairastavan puolisonsa Markun aggressiivisuudesta, joka on lisääntynyt sairauden edetessä. Markun luona käy kotihoito useitakin kertoja päivässä tarpeen mukaan silloin, kun Maire ei ole paikalla. Maire kuitenkin harmittelee sitä, että kotihoidon työntekijät eivät tunnu ymmärtävän, että Markku väittää syöneensä, peseytyneensä tai vaihtaneensa puhtaat alusvaatteet, vaikka oikeasti näin ei ole. Kotihoidon työntekijät lähtevät usein Markun luota todeten, ettei mitään tehtävää ollut. Mairelle jää huoli siitä, että Markun paino laskee, vaikka "paino ei sais tippua ennää yhtään" ja tukka on niin likainen, että "kohtahan siel on täitä". Maire yrittää saada Markun pitämään huolta itsestään ja taistelee hänen kanssaan arjen asioista. Maire ottaa haastattelun aikana yhteensä kolme kertaa esiin, että Markun aggressiivisuus on lisääntynyt ja monista asioista tulee riitaa. Haastattelija kysyy lopuksi, miten Maire itse jaksaa, ja siihen Maire vastaa, että “on se raskasta”. Hän kuvaa oireita, jotka ovat stressille tyypillisiä.

Maire, omaishoitaja: Että justiisa tää, joka asiasta alkaa olla eri mieltä niin kyl se kuluttaa. Kyllä mulla verenpaine rupes nousemaan ja sen takia sitten tuota tuolla, [...] juna-asemalla, niin mua rinnasta puristi niin, et tuntu et mää kuolen siihen paikkaan, et henki loppuu.

Joskus tukea tai palvelua ei ollut tarjottu tai omaishoitaja ei ollut hakenut palveluja. Toisinaan palvelua olisi ollut saatavilla, mutta se ei ollut riittävää, oikea-aikaista tai tarpeeksi joustavaa. Taina olisi mielellään ottanut apua vastaan, koska puolison vaippojen vaihto, ulosteiden peseminen ja siivoaminen oli raskasta. Apua ei ollut kuitenkaan saatavilla niin, että se osuisi sopivaan ja hyödylliseen aikaan: "Kotiapuahan me ois saatu tänne, mut nehän tulee silloin kun ne tulee. Ei mulle oo mitään hyötyä.” Koska kotihoito ei pystynyt tarjoamaan joustavampaa palvelua, Tainalla ei ollut lainkaan tukenaan kotiin saatavaa apua.

Joskus avun riittämättömyys liittyi tiedon puutteeseen: ihmiset eivät yksinkertaisesti tienneet, mihin palveluihin he olisivat oikeutettuja, mistä avusta ja palvelusta he voisivat 
hyötyä ja mistä mitäkin voisi hakea. Puolisoaan hoitava Tuomas on jäänyt ilman tukea, kun hänelle ei ole kerrottu, mihin palveluihin olisi oikeus ja mitä tukea voisi saada: "Minusta tuntuu siltä, että myö on oltu monessa asiassa niin kun pimennossa." Tuomas kuvaa, että kun ei ole tiennyt, mitä apua voisi olla saatavilla tai mihin palveluihin he olisivat oikeutettuja, hän on itse hoitanut asiat. Palvelujen puute on siis merkinnyt omaishoitajalle raskaampaa vastuuta. Tuomaksen sanoin, "et on ite kärsinä".

Toisinaan riittämätön avunsaanti ei liittynyt tiettyyn palveluun vaan hoitokokonaisuuteen. Joskus ihmiset eivät pysty täysin nimeämään, millaista apua heiltä puuttuu. He vain tietävät, että asiat eivät suju, ja kokevat neuvottomuutta, koska eivät ole varmoja, onko heidän tarvitsemaansa apua ylipäänsä tarjolla ja jos on, niin mihin pitäisi ottaa yhteyttä sitä saadakseen. Tyyne on otettu mukaan omaishoitajien vertaisryhmätapaamisiin, vaikka hänellä ei vielä virallista omaishoitosopimusta olekaan. Tämä on avannut hänen silmiään sille, miten hän jää paitsi tarpeellisesta tiedosta.

Tyyne omaishoitaja: No ehdottomasti aattelen, kun tapaan näitten omaishoitajienkin kanssa, niin kyllä niillä varmaan on enemmän tietoo, mut se voi myöskin olla, että he on hakenu. Mä en tiedä, tiedänks mä ees kanavia, mistä lähden semmosta tietoo hakemaan. Mutta paremmin varmaan tulen tästä läbtien saamaan tietoo, kun oon siinä missä on tää... omaishoitajat kokoontuu.

Lasse oli saanut hiljattain omaishoitosopimuksen ja koki, että nyt tietoa palveluista oli paremmin saatavilla. Hän puhui siitä, että julkiselta puolelta palveluohjausta tai tietoa tukipalveluista oli hankalaa saada.

Lasse, omaishoitaja: Mutta kylläbän ne joka paikassa tietysti menee siihen, että sitä perustietoo ei niin kun ikäihminenkää, ni ei sitä sillain ammenna [...] että ny mä oon käyny tota omaishoitajapuoltakin läpitte, että mä oon tos- sa ollu kursseilla ja sillai, että nyt vähän tietää, että mitä mistä pyytää.

Haastattelija: Nii joo. Elikkä sielt on sitte saanu tietoo tämmösistä tukipalveluista ja näistä. Lasse: Joo, siinä mielessä on, että niin ku niinku aina sitä tiedonpyyntöo, ni.

Haastattelija: Mm, onks tää palvelukoordinaattori kertonu jotain vaibtoehtoja mitä vois?

Lasse: No ei sieltäkään kaupungin puitteista, se on aika jäykkää kanssa ja niillä on niin kiire, että ne, no ne sanoo, että kun jos siellä soittaa niin voi mennä parikin päivää ennen ku sieltä vastataan.

Lasse puhuu siitä, että tietoa kyllä on, mutta ikääntynyt ihminen ei aina tiedä, mistä sitä pitäisi hakea tai osata "ammentaa". Omaishoitajien kursseilla tilanne on parantunut, kun siellä on neuvottu, mistä mitäkin voi pyytää. Julkisen sektorin palvelut tuntuvat vaikeasti tavoitettavilta, kun pelkkää puheluun vastaamista voi joutua odottamaan useamman päivän.

\section{Pääsy lääkäriin ja luotettava hoitosuhde}

Yksi kotihoitoon tarvittava tuki ovat lääkäripalvelut, mutta lääkärille oli usein vaikea saada vastaanottoaikaa ja odotusajat olivat pitkiä. Haastateltavat kaipasivat varmuutta ja luottamusta siihen, että terveydenhuollosta on saatavissa apua silloin, kun sitä tarvitaan. Terveydenhuollosta kaivattaisiin myös joustavaa ja nopeaa apua, kun hoidon tarpeet muuttuvat. Odotus ja epätietoisuus saattoivat tuntua kohtuuttomilta, ja haastatelluille tuli myös tunne, että he eivät kerta kaikkiaan saa tarvitsemaansa apua. Usein lääkäriä ei päässyt tapaamaan vaan lääkkeet vain uusittiin puhelimitse, minkä haastatellut kokivat riittämättömäksi. Tyyne kuvasi, miten neurologin käynnit loppuivat yhtäkkiä, ja vaikka hänen puolisollaan Toivolla oli useita neurologisia oireita, he eivät olleet enää päässeet tapaamaan lääkäriä. Myös Elinan puolison, Erkin, muistisairauden tilan seuraaminen oli epätasaista. 
Tyyne, omaishoitaja: Sillon alkuun, mä muistasin niin että kaks vuotta me saatiin käydä siellä neurologilla, [...] mut sitten hän sano, että loppuu nyt tää meijän, että me siirrytään sit omalääkärille ja omalääkärille tääl ei pääse kyllä. [...] Ei tän sairauden puitteissa kyllä oo saatu siis mitään, että sen jälkeen, kun tämä neurologin vastaanottokäynnit loppu [...]. Se oli semmonen turvallinen juttu.

Elina, omaishoitaja: Me ollaan viimeks oltu tuolla, siellä, Alzheimer-lääkärillä, onko siitä kaks vai kolme vuotta. Ei, ei oo tasasta seurantaa, tai mitään, joo.

Lääkäri on avainasemassa muistisairaan hoidon suunnittelussa ja jatkohoitotoimien lähetteiden määräämisessä, minkä vuoksi muistisairaat ja puoliso-omaishoitajat olivat monella tavalla lääkäristä riippuvaisia. Muistisairautta sairastava Anja ja hänen puoliso-omaishoitajansa Aulis kuvaavat ongelmia, joita ovat kokeneet omalääkärin tai -hoitajan kanssa muodostettavassa hoitosuhteessa. Anja ja Aulis eivät ole päässeet lääkärin vastaanotolle silloin, kun ovat kokeneet tarvitsevansa sitä. Hoitosuhde on katkennut muuton yhteydessä, eikä uutta hoitosuhdetta ole muodostunut. He kokevat hoidon olevan puutteellista esimerkiksi lääkkeiden yhteisvaikutusten selvittämisessä. He ovat etsineet sopivaa hoitotahoa ja kierrelleet erilaisten yksityisen, julkisen ja kolmannen sektorin toimijoiden välillä.

Aulis, omaishoitaja: Minun mielestä julkinen terveydenhuolto ei ole [tarjonnut riittävää apua]. [...] Ja kuitenki täällä käytiin vastaanotolla, niin kyllä se biukan tulee se tuntuma [ettei palvelut toimi]. Mä en tiïa mikä Anja ite... Ei se sillai ole toiminu, ku se olis pitäny toimia, varsinki tämän kokosessa kaupungissa.

Anja, muistirairautta sairastava puoliso:Joo, elikkä ainaki mitä mää kävin ensimmäisiä kertoja [terveysasemalla] niin.. Siis se iban ensimmäinen oli aivan huippu. Se oli sairaanboitaja, joka otti niinkö uuden potilaan hei- jän kirjoibin. Se oli kerta kaikkiaan iban halattava. Mut sen jälkeen mä en oo nähny sitä ihmistä ollenkaan.

Aulis: Sitte jos ei ois ollu itse omaa aktiviteettia, ja siiben että ois läbteny niinku kolmannen sektorille hakeutumaan, niin oispa jääny aika vahvasti väliin vuodeksi.

Anja: Ja kyllähän mää kyselin jo siinä muistiryhmässä näiltä objaajilta. Että tietääkö ne byvää, tuota, neurologia yksityistä.

Aulis: Mutta esimerkiksi semmonen asia, että kun on eri sairauksien jobdosta erilaista lääkitystä. Jo sen takia lääkärinvastaanotto, neurologin tai geriatrin ois ollu...

Anja: Niin mä sanoin just et lääkkeiden ybteisvaikutus.

Aulis: ...ollu tärkee. Eli mikä on lääkkeiden yhteisvaikutus.

Lääkärin vastaanottoaikojen puute ja se, etteivät muistisairautta sairastavat $\mathrm{ja}$ heidän omaishoitajansa tienneet, mistä oikein saada tai vaatia apua, johti toisinaan tilanteisiin, joissa muistisairautta sairastava ja hänen omaisensa kokivat jääneensä yksin selviytymään epäselvässä tilanteessa. Julkisella sektorilla ammattilaiset arvioivat tarpeita ja päättävät palveluihin pääsystä. Harva käytti yksityisen sektorin lääkäripalveluja.

Riitta ja Reijo kuvaavat haastattelun aikana useampaan kertaan, miten heidät "on jätetty". Reijon saama diagnoosi ei täysin vastaa heidän kokemustaan arjesta, mutta Reijo ei pääse uudestaan tutkittavaksi, jotta tilanteeseen saataisiin lisää selvyyttä.

Riitta, omaishoitaja: Että siel ei tosiaan geriatrilla käyty kun kaks kertaa. Jonka jälkeen sitten siirrettiin omalääkärille. Et sen jälkeen ei olla oltu erikoislääkärillä. [...] Et tavallaan välillä tuntu, että se oli jätetty oman onnensa nojaan. [...] jotain kaipais. Tästä, kun ei tosiaan se oli kaks kertaa ja sitten siirrettiin terveyskeskukseen ja, no siellä tietysti muistitestit ja yleislääkäri...on ollu mutta... [...] 
Haastattelija: Joo. Tuntuuks teistä et se vois olla väärä diagnoosi?

Riitta: No välillä tulee semmonen tunne. Et onks se sit Alzheimeria vai onks se sit [naurahtaen] jotain muuta. Muistihoitajahan kävi alussa.

Reijo, muistisairautta sairastava puoliso: Niin joo, se kävi kaks kolme kertaa. Kolmena vai k-kahtena vuonna alkuun. [...] Eiks se käyny kaks kertaa?

Riitta: Kaks oli, ei enempää.

Riitta ja Reijo kokevat jääneensä epätietoisuuteen siitä, mikä muistisairaus Reijolla lopulta on. Epätietoisuus on omiaan aiheuttamaan huolta ja epävarmuutta sekä tunteen siitä, että he eivät saa riittävää ja asianmukaista lääkärin hoitoa.

\section{Henkinen tuki}

Muistisairauteen liittyvistä tilanteista keskusteleminen on tärkeää niin puolisoaan hoitavalle omaiselle kuin sairastuneelle itselleen. Haastateltavat toivoivat mahdollisuuksia keskustella sekä ammattilaisten että läheisten ja ystävien kanssa tilanteestaan ja puolison hoivaan liittyvistä asioista. Omaishoitajat kokivat muistisairautta sairastavan puolisonsa tilanteen usein vaikeaksi ja itsensä neuvottomaksi puolisonsa monimuotoisten oireiden vuoksi. Osa muistisairaista myös kaipasi henkilöä, jonka kanssa puhua tilanteestaan ja sairauden vaikutuksista elämään.

Osa haastatelluista koki, ettei pysty puhumaan ystäviensä ja läheistensä kanssa avoimesti ja rehellisesti tilanteestaan, sillä muiden ihmisten voi olla vaikea ymmärtää, millaista elämä muistisairauden kanssa on ja millaisia asioita omaishoitajan arjessa tulee eteen. Jotkut haastateltavat kokivat, että ystävät ovat kaikonneet muistisairauden myötä. Helena kertoi ystävien hävinneen "heti oikeestaan [...] eipä oo ketään näkyny". Mikko ihmetteli haastattelussa, miksi on käynyt niin, että pariskunnan aiemmin vilkas sosiaalinen elämä on kuihtunut kokonaan:
"Tekis mieli kysyä, että mikä siihen on syynä, kun ennen vanhaan joka viikko ja monestiki viikossa, niin nyt ei sitte kutsuja tule ollenkaa." Myös Tuomas kertoi tuttavien kadonneen puolison sairauden myötä:"Kaikki tutut ne pelkää, että tää sairaus tarttuu."

Jotkut haastateltavat totesivat haastattelutilanteen olevan juuri sellainen hetki, jota he kaipasivat: saa rauhassa keskustella jonkun ihmisen kanssa, joka on kiinnostunut omaishoitajan ja muistisairautta sairastavan tilanteesta. Osa halusikin tutkimukseen mukaan sen vuoksi, että he voisivat kertoa elämästään niin, että joku keskittyy kuuntelemaan.

Omaishoitajana toimiva Marianne kertoo, miten paljon neuvottomuutta aiheuttavat hänen puolisonsa, Martin, muistisairauteen liittyvät etenevät oireet. Marianne kuvaa monen muun haastattelemamme omaishoitajan tavoin, miten hän tarvitsisi keskusteluapua, koska hänen läheisensä joko asuvat kaukana tai eivät ymmärrä tilanteen vakavuutta. Marianne kertoi ongelmana olevan myös, että muistisairas puoliso pystyy käyttäytymään niin, ettei vieraampi ihminen tajua, että hänellä on muistisairaus, eivätkä heidän avuntarpeensa tule tunnistetuiksi.

Haastattelija: Jos aattelet ihan konkreettisesti, et niin millanen se apu olis mitä kaipaisit mitä nyt ei saa?

Marianne, omaishoitaja: No tää on jo hyvä. Tää on jo hyvä, että sain pubua. Et on sellanen ibminen ja rauballinen ympäristö ja näi, ku ei mulla ole täällä, ni läbeiset on kaikki tuolla. No, ystäville oon pubunu jonkin verran, mutta he ei ymmärrä mitä on elää muistisairaan kanssa. Martti on niin byvä näyttelijä, se skarppaa, meille kun tulee kylään ibmisiä ja näi, ni nebän on iha että voiko olla.

Jotkut haastateltavista olivat saaneet keskusteluapua mielenterveyshoitajan tai psykiatrisen sairaanhoitajan kotikäynneillä. Se on usein kuitenkin vain väliaikaista, vaikka haastateltavat haluaisivat keskusteluavun jatkuvan 
niin kauan kuin he itse kokevat siihen tarvetta. Muistisairautta sairastava Orvokki kertoi, miten hän oli aiemmin saanut keskusteluapua geropsykiatrisen sairaanhoitajan kotikäynneillä.

Olavi, omaishoitaja: Geropsykiatrinen sairaanhoitajahan kävi, täällä aika pitkän aikaa. Ei nyt ihan joka viikko.

Orvokki, muistisairautta sairastava puoliso: Juu, ihan, keskusteltiin vaan ihan normaalisti. Hän oli mukava, mutta valitettavasti se loppui sitten kun, on tietysti, en ole ainoa henkilö, joka tarvitsee semmosta. [...] Ei näitten, öo, ystävieni kanssa, ei voi jutella sillai yhtään syvemmin. Niin se on, mutta mä en tiedä mikä semmonen tie on, että löytäis semmosen ibmisen, jonka kanssa vois...

Haastattelija: Niin, keskustella sitte syvällisesti.

Orvokki: Keskustella niin. Ja vois kertoa niitä omia kokemuksia mitä mulla on.

Orvokki piti keskusteluja sairaanhoitajan kanssa hyödyllisinä, mutta käynnit lopetettiin. Orvokki ei koe, että voisi keskustella esimerkiksi ystäviensä kanssa samalla tavalla asioista, joten keskusteluavun loppuminen jätti aukon hänen hoitoonsa.

\section{Johtopäätökset}

Tutkimuksessamme selvitimme, millaista tukea kotona asuvat muistisairaat ihmiset ja heitä hoitavat puolisot kaipaavat ja millaisia kokemuksia heillä on avun riittämättömyydestä. Puoliso-omaishoitajat kuvasivat useita päivittäisiin toimiin liittyviä vaikeita, kuormittavia ja hämmentäviä tai jopa uhkaavia tilanteita,joista oli selviydyttävä ilman muiden apua, kun sitä ei ollut saatavilla. Omaishoitajana toimivat puolisot huolehtivat muistisairautta sairastavasta kumppanistaan silloinkin, kun apua ja palveluja pitäisi selvästi saada julkisista palveluista. Näin avun riittämättömyys kasaantui omaishoitajille eikä niinkään muistisairautta sairastavalle hen- kilölle. Omaishoitajat kuvasivat avun riittämättömyyttä, joka liittyi kotona asumista tukeviin palveluihin: vuorohoitoon, kotihoidon palveluihin sekä terveyspalveluihin, erityisesti hoitosuhteeseen lääkärin kanssa.

Tutkimukseemme osallistuneet omaishoitajat eivät käyttäneet vuorohoitoa, johon heillä olisi ollut oikeus ja joka olisi mahdollistanut heille tarpeellista vapaa-aikaa ja lepoa, jos tarjottu hoito ei ollut heidän mielestään riittävää eikä laadukasta. Omaishoitajat jäivät ennemmin itse ilman kovasti tarvitsemaansa vapaaaikaa kuin veivät puolisonsa hoitopaikkaan, jossa hoito ei ollut hyvää. Kotihoidon palvelut eivät välttämättä olleet kyllin joustavia, tai omaishoitajien tarpeet olivat sellaisia, että niihin oli vaikeaa sovitella palvelua, ja siksi omaishoitajien tarvitsema apu jäi saamatta.

Helposti saatavilla olevat kotiin tarjottavat tukipalvelut sekä toimiva vuorohoito ovat parasta tukea omaishoitajille, ja niiden avulla voidaan vähentää omaisten kuormitusta (Jarrot ym. 2005; Salin \& Åsted-Kurki 2007). Ilman riittävää tukea omaishoitajien kuormitus voi johtaa tilanteeseen, jossa muistisairaalle tarvitaan ympärivuorokautista hoitoa aikaisemmin kuin sitä tarvittaisiin, jos omaishoitaja jaksaisi huolehtia läheisestään. Omaishoitajan kohtuuttomiksi ajautuvat tilanteet voivat myös kuormittaa palvelujärjestelmää epätarkoituksenmukaisella tavalla. Tällaisesta kertoi haastateltava, joka soitti välillä uupuneena ambulanssin, kun ei tiennyt enää, mitä tehdä öisin levottomana vaeltavalle miehelleen.

Toimittaessa terveydenhuollon kanssa hoitosuhteessa vallitsee vallan epäsuhta (power imbalance) (Burkitt 2016; Berry ym. 2017). Se saattaa vaikeuttaa asiakkaan ja hoitohenkilökunnan välistä kommunikaatiota, jolloin esimerkiksi hoidon kannalta tärkeitä asioita ei tule esille virallista hoitajaa tavattaessa (Berry ym. 2017). Vallan epäsuhta oli nähtävissä lääkäripalveluihin liittyvässä riittämättömässä avussa: lääkärille oli vaikea saada aikaa, vaikka muistisairauksien hoitoon kaivattiin pitkäaikaista hoitosuhdetta. Jotkut haastateltavat 
olivat epätietoisia muistisairauden lopullisesta diagnoosista, lääkkeiden yhteensopivuudesta sekä muista hyvin tärkeistä muistisairauden ja muiden sairauksien hoitoon liittyvistä kysymyksistä. Onnistuneet tulokset muistisairauksien hoidossa edellyttäisivät jatkuvaa, yksilöllistä hoitoa (Eloniemi-Sulkava ym. 2015; Fazio ym. 2018), mutta tämä ei aina toteutunut. Hoidon jatkuvuutta sekä selkeää ja avointa asiakkaan ja asiakkaan omaisten kanssa käytävää kommunikaatiota pitäisi lisätä, mikäli halutaan tukea muistisairaan iäkkään ihmisen koti- ja omaishoitoa.

Palvelukokonaisuuksien sekavuus ja tämän aiheuttama kokemus avun riittämättömyydestä oli melko yleistä varsinkin niillä, joilla avuntarpeet olivat moninaisia. Jotkut haastatellut kokivat, että kukaan palvelujärjestelmässä ei tunnu olevan vastuussa hoidon koordinoinnista. Tällöin asiakkaat - ja muistisairaiden kohdalla myös heitä hoitavat omaiset - kärsivät palvelujen pirstaloituneisuudesta ja väsyvät etsimään oikeita palveluja (Hujala \& Lammintakanen 2018). Siten he saattoivat jäädä vaille apua, jota he tarvitsisivat, tai avun saaminen saattoi kestää kohtuuttoman kauan tai vaatia kohtuuttomia ponnistuksia. Eri palvelujen integraatio ja hoidon jatkuvuuden parantaminen selkeyttäisi muistisairautta sairastavien hoitoa (van Walraven ym. 2010) ja vähentäisi riittämätöntä avunsaantia.

Tukipalvelujen ja terveyspalvelujen lisäksi keskeinen avun riittämättömyyden osa-alue oli henkinen tuki. Sekä muistisairauteen sairastuneet että omaishoitajat kaipasivat mahdollisuutta keskustella tilanteestaan ja jakaa ajatuksiaan jonkun kanssa. Keskusteluapua ei kuitenkaan yleensä ollut saatavilla, tai jos sitä oli saatu, se oli haastateltavien mukaan ollut vain määräaikaista. Muistisairautta sairastavien henkilöiden omaishoitajien kokema henkisen tuen puute on havaittu aiemmissakin tutkimuksissa (mm. Tatangelo ym. 2018). Tulostemme mukaan muistisairauksien hoito keskittyi diagnosointiin, muistisairauden vakavuuden tes- taamiseen sekä lääkehoitoon, mutta henkinen tuki jäi usein puuttumaan.

Säännöllinen keskusteluapu olisi tärkeää myös omaishoitajien tilanteen seuraamiseksi ja mahdollisten kasvavien palvelutarpeiden tunnistamiseksi sekä uupumisen ennusmerkkien huomaamiseksi. Omaishoitajille järjestettävä henkinen tuki ei välttämättä olisi kunnille menoerä, vaan se voisi tuoda kustannussäästöjä ehkäisemällä muistisairautta sairastavien laitosmaisen hoidon tarpeita (ks. myös Kehusmaa 2014). Palvelujärjestelmää tulisikin kehittää niin, että keskusteluapu kuuluisi automaattisesti sairastuneille ja heidän läheisilleen tarjottaviin palveluihin. Tämä voitaisiin toteuttaa esimerkiksi terveydenhoitajan tapaamisella, jonka tarkoitus olisi kartoittaa henkistä jaksamista. Muistisairaat ja heidän omaisensa tulisi lisäksi ohjata järjestöjen vertaistukitoiminnan tai muun omaishoitajien jaksamista tukevan toiminnan pariin.

Tutkimuksemme mukaan avun riittämättömyyden kokemuksia oli eniten silloin, kun muistisairauteen liittyi monimuotoisia ja vaativia tarpeita. Vaikeissa ja vaativissa tilanteissa omaishoitajat kokevat, että palveluista saatu apu ja tuki ei ole riittävää. Mitä vaativampaa hoivaa ja hoitoa muistisairas tarvitsee, sitä kuormittavampaa omaishoito on, ja sitä enemmän on tarvetta tukipalveluille. Palveluista saatava apu ei kuitenkaan aina lisäänny sitä mukaa, kun sen tarve kasvaa. Tähän tarvittaisiin palveluohjausta ja sitä, että omaishoitajat saisivat tietoa tarjolla olevista tukimuodoista sekä palvelujen hakemisesta. Hoitokokonaisuuksien ja hoidon jatkuvuuden puute koskettaa entistä suurempaa joukkoa muistisairautta sairastavia ja heidän läheisiään, koska muistisairaiden ihmisten määrä eri sosiaali- ja terveyspalvelujen asiakkaina kasvaa koko ajan.

Tarpeenmukaisen ja onnistuneen hoidon takaaminen edellyttää palvelurakenteen selkeyttämistä, kokonaisvaltaisempaa tarpeiden - myös henkisten tarpeiden - huomioimista sekä selkeämpää ja tasa-arvoisempaa viestintää 
eri tahojen välillä. Palvelujärjestelmässä pitäisi olla mahdollista ottaa paremmin huomioon muistisairautta sairastavien ja heitä hoitavien omaisten näkemykset.

\section{Tutkimuksen rajoitukset}

Vaikka haastattelut pyrittiin järjestämään niin, että sekä muistisairautta sairastavat henkilöt että omaishoitajat saattoivat osallistua ja molempien näkemykset tulisivat aineistossa esiin, oli omaisten ääni lopulta vahvempi kuin muistisairaiden jo pelkästään siitä syystä, että omaishoitajat puhuivat haastatteluissa enemmän. Muistisairaudet aiheuttavat kognition heikkenemistä, mikä voi vaikeuttaa keskusteluun osallistumista ja haastattelijan kysymysten ymmärtämistä. Siten muistisairaiden osallistuminen haastatteluihin on usein vähäisempää kuin omaisten (mm. Bosco ym. 2019; Poutiainen ym. 2020). Pariskunnilla voi myös olla keskustelutilanteissa jo aiemmin totuttuja keskusteluja vuorovaikutustapoja,jotka eivät suoranaisesti liity muistisairauteen.

Vaikka muistisairauteen sairastuneet toivat näkemyksiään esiin vähemmän kuin heidän omaisensa, oli heidän osallistumisensa kuitenkin tärkeää ja heidän näkemyksensä lisäsivät tutkimuksen tuottamaa tietoa. Muistisairauksiin liittyvissä tutkimuksissa keskitytään usein omaisten kokemuksiin, mutta tutkimuksemme osoittaa, että muistisairautta sairastavien osallistuminen on mahdollista.

Tutkimuksen rajoitteena voidaan pitää sitä, että haastateltavamme rekrytoitiin kahden järjestön kautta. On oletettavaa, että järjestöjen toimintaan aktiivisesti osallistuvat - ja tutkimukseen vapaaehtoisesti ilmoittautuvat - edustavat aktiivisten ihmisten joukkoa.
Suomessa on myös muistisairaita, kotona asuvia ihmisiä, joilla ei ole asuinkumppania auttamassa, jolloin myös kokemukset kotiin tarvittavasta tuesta ja avun riittämättömyydestä ovat varmasti erilaista.

Aineistomme rajallisuuden vuoksi tutkimuksemme tulokset eivät ole yleistettävissä kaikkiin muistisairautta sairastaviin ja omaishoitajiin. Tuloksemme kertovat kuitenkin avun riittävyydestä, palveluista ja arjessa kohdatuista tilanteista, jotka koskevat monia vastaavassa tilanteessa eläviä. Laadullisella aineistolla voidaan saada tietoa siitä, millaisia kokemuksia ihmiset mahdollisesti kohtaavat tietyissä tilanteissa ja olosuhteissa. Kokemukset ovat usein jaettuja ja tunnistettavia; niissä on yhteisiä piirteitä ja samankaltaisuutta. Yksittäisten haastattelujen tarinat liittyvät yhteen, ja niiden samankaltaisuutta ja erilaisuutta tarkastelemalla voidaan selvittää, mikä kotona asumiseen tarvittavassa tuessa on merkittävää ja mitkä ongelmat kenties toistuvat myös yleisemmän tason tarkastelussa.

Tämän tutkimuksen ovat mahdollistaneet Suomen Kulttuurirahaston Pirkanmaan aluerahaston Aino Valvaalan rahastosta Mari Aaltoselle myönnetty työrybmäapuraha, Suomen Akatemian Ikääntymisen ja hoivan tutkimuksen huippuyksikkö (CoE AgeCare, projektinro 312303) sekä Suomen Akatemian Mari Aaltoselle myöntämä tutkijatohtorirahoitus (päätösnro 326404).

\section{Yhteydenotto:}

Lina Van Aerschot, YtT, tutkijatohtori

Humanistis-yhteiskuntatieteellinen tiedekunta Ikääntymisen ja hoivan tutkimuksen huippuyksikkö Jyväskylän yliopisto

lina.vanaerschot@jyu.fi 


\section{Kirjallisuus}

Aaltonen M, Van Aerschot L. Unmet needs are common among community-dwelling older people with memory problems in Finland. Scand J Public Health 2021;49(4):423-32. https://doi.org/10.1177\%2F1403494819890800

Atula S. Vaskulaarinen dementia (verenkiertoperäinen muistisairaus). Lääkärikirja Duodecim. 2019. Internet: https://www.terveyskirjasto.fi/terveyskirjasto/tk.koti?p_artikkeli=dlk01106 (viitattu 13.1.2021).

Berry LL, Danaher TS, Beckham D, Awdish RLA, Mate KS. When patients and their families feel like hostages to health care. Mayo Clin Proc 2017;92(9):1373-81. https://doi.org/10.1016/j.mayocp.2017.05.015

Black BS, Johnston D, Rabins PV, Morrison A, Lyketsos C, Samus QM. Unmet needs of community-residing persons with dementia and their informal caregivers: findings from the maximizing independence at home study. J Am Geriatr Soc 2013; 61:2087-95. https://doi.org/10.1111/jgs.12549

Blake M, Lambert C, Siganporia Z. Unmet need for care. Research report, IPSOS Mori. 2017. Internet: https://www.ipsos.com/sites/default/ files/2017-07/unmet-need-for-care-full-report. pdf (viitattu 15.11.2020).

Blomgren J, Martikainen P, Martelin T, Koskinen S. Ikääntyneiden saama epävirallinen ja virallinen apu Suomessa. Yhteiskuntapolitiikka 2006;71(2):167-78.

Bosco A, Schneider J, Coleston-Shields DM, Jawahar K, Higgs P, Orrell M. Agency in dementia care: systematic review and meta-ethnography. Int Psychogeriatr 2019;31(5):627-42. https://doi.org/10.1017/S1041610218001801

Burkitt I. Relational agency: relational sociology, agency and interaction. Eur J Soci Theory 2016;19(3):322-39. https://doi.org/10.1177/1368431015591426

Chester H, Clarkson P, Davies L, Sutcliffe C, Davies S, Feast A, Hughes J, Challis, D. People with dementia and carer preferences for home support services in early-stage dementia. Aging Ment Health 2018;22(2):270-9. https://doi.org/10.1080/13607863.2016.1247424

Digby R, Lee S, Williams A. Interviewing people with dementia in hospital: recommendations for researchers. J Clin Nurs 2016;25(7-8):1156-65. https://doi.org/10.1111/jocn.13141

Eloniemi-Sulkava U, Juva K, Mäkelä M. Kotonaasuvan muistisairaan hoito ja ympärivuorokautiseen hoitoon siirtymisen ehkäisy. Teoksessa: Erkinjuntti T, Remes A, Rinne J, Soininen $\mathrm{H}, \mathrm{Ala}-$ fuzoff I, Piispa S, toim. Muistisairaudet. 2. uud. p. Helsinki: Duodecim, 2015:506-19.

Eloniemi-Sulkava U, Sormunen S, Topo P. Dementia on erityiskysymys. Teoksessa: Sormunen S, Topo P, toim. Laadukkaat dementiapalvelut. Opas kunnille. Helsinki: Stakes, 2008:9-14.

Fazio S, Pace D, Flinner J, Kallmyer B. The fundamentals of person-centered care for individuals with dementia. Gerontologist 2018;58(1):S10 S19 https://doi.org/10.1093/geront/gnx122

Feast, A. Behavioural and psychological symptoms in dementia and the challenges for family carers: systematic review. Br J Psychiatry 2016;208(5):429-34. https://doi.org/10.1192/bjp.bp.114.153684

Finne-Soveri H, Heikkilä R, Mäkelä M, Asikainen J, Vilkko A, Andersson S, ym. Mitä on huomioitava vanhusten laitoshoitoa vähennettäessä. Teoksessa: Noro A, Alastalo H, toim. Vanhuspalvelulain 980/2012 toimeenpanon seuranta. Tilanne ennen lain voimaantuloa vuonna 2013. Helsinki: THL, 2014:56-70.

Finne-Soveri H, Kuusterä K, Tamminen A, Heimonen SL, Lehtonen O, Noro A. Muistibarometri 2015 ja RAI-tietoa kansallisen muistiohjelman tueksi. Helsinki: THL, 2015. Internet: http:// urn.fi/URN:ISBN:978-952-302-565-3 (viitattu 12.12.2020).

Heikkilä R, Mäkelä M, Noro A, Lammintakanen J, Laulainen S. Millaisilla palveluilla enintään keskivaikeasti oireilevat muistisairautta sairastavat henkilöt pärjäävät kotona? Gerontologia 2020;34(2):74-87.

https://doi.org/10.23989/gerontologia.84723

Hubbard G, Downs MG, Tester S. Including older people with dementia in research: challenges and strategies. Aging Ment Health 2003;7(5):351-62. https://doi.org/10.1080/1360786031000150685

Hujala A, Lammintakanen J. Paljon sote-palveluja tarvitsevat ihmiset keskiöön. Kunnallisalan kehittämissäätiön Julkaisu 12, 2018.

Isaacs B, Neville Y. The measurement of need in older 
people. Edinburgh: Scottish Home and Health Department, 1976.

Jarrot SE, Zarit SH, Parris Stephens MA, Townsend A, Greene R. Instrumental help and caregivers' distress: effects of change in informal and formal help. Am J Alzheimers Dis Other Demen 2005;20(3):181-90.

https://doi.org/10.1177/153331750502000308

Jensen CJ, Inker J. Strengthening the dementia care triad: identifying knowledge gaps and linking to resources. Am J Alzheimers Dis Other Demen 2015;30(3):268-75.

https://doi.org/10.1177/1533317514545476

Juva K. Alzheimerin tauti. Lääkärikirja Duodecim. 2018. Internet: https://www.terveyskirjasto.fi/ terveyskirjasto/tk.koti?p_artikkeli=dlk00699 (viitattu 15.1.2021).

Kehusmaa S. Hoidon menoja hillitsemässä: heikkokuntoisten kotona asuvien ikäihmisten palvelujen käyttö, omaishoito ja kuntoutus. Kelan tutkimusosasto: Sosiaali- ja terveysturvan tutkimuksia 131, 2014.

Kehusmaa S, Autti-Rämö I, Rissanen P. Omaishoidon vaikutus ikääntyneiden hoidon menoihin. Yhteiskuntapolitiikka 2013;78(2):138-51.

Kerpershoek L, de Vugt M, Wolfs C, Actifcare Consortium. Needs and quality of life of people with middle-stage dementia and their family carers from the European Actifcare study: when informal care alone may not suffice. Aging Ment Health 2018;22(7):897-902. https://doi.org/10.1080/13607863.2017.1390732

Kröger T, Van Aerschot L, Puthenparambil JM. Hoivatyö muutoksessa: suomalainen vanhustyö pohjoismaisessa vertailussa. Jyväskylän yliopisto, YFI-julkaisuja, 2018. http://urn.fi/URN:ISBN:978-951-39-7372-8

Kröger T, Van Aerschot L, Puthenparambil JM. Ikääntyneiden hoivaköyhyys. Yhteiskuntapolitiikka 2019;8(2):124-34.

Kuntaliitto. Iäkkäiden palvelut: Omaishoito. 2020. Internet: https://www.kuntaliitto.fi/sosiaali-ja-terveysasiat/sosiaalihuolto/iakkaiden-palvelut/omaishoito\#Palvelut\%20hoidettavalle (viitattu 14.10.2020).

Laki omaishoidon tuesta 2.12.2005/937. Internet:

https://www.finlex.fi/fi/laki/ajantasa/2005/20050937

Lima JC, Allen SM. Targeting risk for unmet need: not enough help versus no help at all. J Geron- tol B Psychol Sci Soc Sci 2001;56(5):S302-10 https://doi.org/10.1093/geronb/56.5.s302

Luchetti L, Uhunmwangho E, Dordoni G, Lorido A, Barbieri S, Bolognesia, ym. 2009. The subjective feeling of burden in caregivers of elderly with dementia: how to intervene? Arch Gerontol Geriatr 2009;49(Suppl 1):153-61.

https://doi.org/10.1016/j.archger.2009.09.025

McCabe L, Robertson J, Kelly F. Scaffolding and working together: a qualitative exploration of strategies for everyday life with dementia, Age Ageing 2018; 47(2):303-10.

https://doi.org/10.1093/ageing/afx186

McCabe M, You E, Tatangelo G. Hearing their voice: a systematic review of dementia family caregivers' needs. Gerontologist 2016; 56(5):e70-80. https://doi.org/10.1093/geront/gnw078

Mikkola T. Sinusta kiinni - tutkimus puolisohoivan arjen toimijuuksista. Akateeminen väitöskirja, Helsingin yliopisto. Diakonia-ammattikorkeakoulun julkaisuja A Tutkimuksia 21, 2009.

Mossello E, Caleri V, Razzi E, Di Bari M, Cantini C, Tonon E, ym. Day care for older dementia patients: favorable effects on behavioral and psychological symptoms and caregiver stress. Int J Geriatr Psychiatry 2008;23(10):1066-72. https://doi.org/10.1002/gps.2034

Omaishoitajaliitto. Mitä on omaishoito? 2020. Internet: https://omaishoitajat.fi/omaishoidon-tietopaketti/mita-on-omaishoito/ (viitattu 25.9.2020).

Phillipson L, Magee C, Jones S. Why carers of people with dementia do not utilize out-of-homerespite services. Health Soc Care Community 2013; 214:411-22. https://doi.org/10.1111/hsc. 12030

Poutiainen S, Kytö S, Virtanen I, Pekkala S. Parisuhdediskurssit muistisairaiden ihmisten ja puolisoiden haastattelupuheessa. Gerontologia 2020;34(1):4-24.

https://doi.org/10.23989/gerontologia.79717

Pozzebon M, Douglas J, Ames D. Spouses' experience of living with a partner diagnosed with a dementia: a synthesis of the qualitative research. Int Psychogeriatr 2016;28(4):537-56. https://doi.org/10.1017/S1041610215002239

Remes A, Haanpää R, Suhonen NM, Junttila A, Solje E. Otsalohkodementia - salakavala muistisairaus. Lääkärilehti 2018; 73(1-2):37-43.

Ringer TJ, Wong-Pack M, Miller P, Patterson C, Marr S, Misiaszek B, ym. Understanding the educational and support needs of informal care-giv- 
ers of people with dementia attending an outpatient geriatric assessment clinic. Ageing Soc 2018;8(28):1-24. https://doi.org/10.1017/S0144686X18000971

Salin S, Åstedt-Kurki P. Women's views of caring for family members: use of respite care. J Gerontol Nurs 2007;33(9):37-45. https://doi.org/10.3928/00989134-20070901-07

Shemeikka R, Buchert U, Pitkänen S, Pehkonen-Elmi T, Kettunen A. Omaishoitajien tarvitsemat tukitoimet tehtävässä selviämiseen. Valtioneuvoston selvitys- ja tutkimustoiminnan julkaisusarja 37/2017.

Silvasti T. Sisällönanalyysi. Teoksessa: Massa I, toim. Polkuja yhteiskuntatieteelliseen ympäristötutkimukseen. Helsinki: Gaudeamus, 2014, 33-49.

Sosiaali- ja terveysministeriö. Kansallinen omaishoidon kehittämisohjelma, Työryhmän loppuraportti. Sosiaali- ja terveysministeriön raportteja ja muistioita 2014:2. Internet: https://omaishoitajat.fi/wp-content/uploads/2017/03/KOHO_raportti.pdf (viitattu 25.9.2020).

Stoltz P, Uden G, Willman A. Support for family carers who care for an elderly person at home a systematic literature review. Scand J Caring Sci 2004;18(2):111-9.

https://doi.org/10.1111/j.1471-

6712.2004.00269.x

Tatangelo G, McCabe M, MacLeod A, You E. "I just don't focus on my needs." The unmet health needs of partner and offspring caregivers of people with dementia: A qualitative study. Int J Nurs Stud 2018;77:8-14. https://doi.org/10.1016/j.ijnurstu.2017.09.011

THL. Hyvinvointi, terveys ja toimintakyky: Muistisairaat asiakkaat sosiaali- ja terveyspalveluissa. Terveyden ja hyvinvoinnin laitos, 2017. Internet: https://sotkanet.fi/sotkanet/fi/index (viitattu 7.5.2020).
THL. Muistisairauksien yleisyys. Terveyden ja hyvinvoinnin laitos, 2019. Internet: https://thl.fi/ fi/web/kansantaudit/muistisairaudet/muistisairauksien-yleisyys (viitattu 4.3.2019).

THL. Omaishoito ja perhehoito. Terveyden ja hyvinvoinnin laitos, 2020. Internet: https://thl.fi/ fi/web/ikaantyminen/muuttuvat-vanhuspalvelut/omaishoito-ja-perhehoito (viitattu 1.6.2020).

Tuomi J, Sarajärvi A. Laadullinen tutkimus ja sisällönanalyysi. Helsinki: Tammi, 2009.

Van Aerschot L. Vanhusten hoiva ja eriarvoisuus, sosiaalisen ja taloudellisen taustan yhteys avun saamiseen ja palvelujen käyttöön. University of Tampere: Tampere University Press, 2014. Internet: https://urn.fi/URN:ISBN:978-951-44-9568-7

van Exel J, Moree M, Koopmanschap M, Goedheijt T, Brower W. Respite care - an explorative study of demand and use in Dutch informal caregivers. Health Policy 2006;78(2-3):194-208. https://doi.org/10.1016/j.healthpol.2005.11.002

Van Walraven C, Oake N, Jennings A, Forster AJ. The association between continuity of care and outcomes: a systematic and critical review. J Eval Clinical Pract 2010;16(5): 947-56.

https://doi.org/10.1111/ j.1365-2753.2009.01235.x

Viramo P, Sulkava R. Muistisairauksien epidemiologia. Teoksessa: Erkinjuntti T, Remes A, Rinne J, Soininen H, Alafuzoff I, Piispa S, toim. Muistisairaudet. 2. uud. p. Helsinki: Duodecim, 2015:35-43.

Vlachantoni A. Unmet need for social care among older people. Ageing Soc 2019;39(4):657-84. https://doi.org/10.1017/S0144686X17001118

Zhou Y, Slachevasky A, Calvo E. Health conditions and unmet needs for assistance to perform activities of daily living among older adults with dementia in Chile. Int J Geriatr Psychiatry 2018; 33(7):964-71. https://doi.org/10.1002/gps.4879 